\title{
Effects of Variety and Spacing on Yield Indices of Open-Pollinated Maize in Asaba Area of Delta State
}

\author{
E. C. Enujeke ${ }^{1}$ \\ ${ }^{1}$ Department of Agronomy, Delta State University, Asaba Campus, Nigeria \\ Correspondence: E. C. Enujeke, Department of Agronomy, Delta State University, Asaba Campus, Nigeria. \\ E-mail: enujeke@yahoo.com
}

Received: May 13, 2013 Accepted: June 13, 2013 Online Published: June 15, 2013

doi:10.5539/sar.v2n4p1 URL: http://dx.doi.org/10.5539/sar.v2n4p1

\begin{abstract}
This study was carried out in the Teaching and Research Farm of Delta State University, Asaba Campus (Nigeria) from March to December in 2008 and replicated between March and December, 2009, to evaluate the effects of variety and spacing on yield indices of Open-pollinated maize. It was a factorial experiment carried out in a Randomized Complete Block Design (RCBD) with four replicates. Four open-pollinated varieties (Suwan -1- SR, ACR97, BR9922-DMRSF 2 and AMATZBRC 2 WB) were evaluated under three different plant spacing for such yield indices as number of cobs/plant, cob length, grain weight and number of grains/cob of maize. The results obtained indicated that variety BR9922-DMRSF 2 was outstanding with number of cobs/plant of 1.7 in both 2008 and 2009, cob length of $27.7 \mathrm{~cm}$ and $26.7 \mathrm{~cm}$ in 2008 and 2009, respectively. Its grain weight was $4.7 \mathrm{t} / \mathrm{ha}$ in 2008 and $4.9 \mathrm{t} / \mathrm{ha}$ in 2009, and its number of grain/cob was 467.7 in 2008, and 463.9 in 2009. Plants sown at spacing of $75 \mathrm{~cm} \times 15 \mathrm{~cm}$ had higher number of cobs/plant of 1.9 in both 2008 and 2009 . Their grain weights (t/ha) were 5.0 in 2008 and 5.2 in 2009 , their cob lengths were $18.6 \mathrm{~cm}$ in 2008 and $20.1 \mathrm{~cm}$ in 2009 , while their number of grains/cob were 363.0 in 2008, and 369.0 in 2009. The results of interaction showed that except variety $x$ space, the parameters investigated were all significantly $(\mathrm{P}<0.05)$ different and affected yield indices of open-pollinated maize. Based on the findings of the study, it was recommended that (i) open-pollinated variety BR9922-DMRF 2 be grown in the study area for increased grain yield indices of maize. (ii) Plant spacing of 75 $\mathrm{cm} \times 15 \mathrm{~cm}$ which resulted in higher number of cobs/plant and higher grain weight be adopted in maize production.
\end{abstract}

Keywords: Asaba, Nigeria, open-pollinated maize, variety and spacing, yield indices

\section{Introduction}

Among the cereals, maize (Zea mays L.) is one of the most important crops grown in the humid tropics and sub-Saharan Africa. In world production, Food and Agriculture Organization (FAO, 2002), ranked the maize crop as third following wheat and rice. Today, millions of people in the world depend on maize for food and livelihood. Maize is consumed roasted, boiled, fried, pounded or fermented (Agbato, 2003). In developed countries, it is an important source of such industrial products as corn sugar, corn oil, flour, starch, syrup, brewers' grit and alcohol (Dutt, 2005). Maize is a major component of livestock feed, and it is palatable to pigs, goats, sheep, cattle and poultry (Enujeke, 2013). In spite of the economic importance and high demand for maize in Nigeria, rapid reduction in soil fertility, failure to identify high yielding varieties and negligence of soil amendment materials have interplayed to decrease yield to as low as $1 \mathrm{t} / \mathrm{ha}$. (DIPA, 2006; Kim, 1997; Olakojo, 1993). Research work by IITA (2001) and Iken et al. (2001) indicated that open-pollinated maize varieties are more appropriate to peasant farmers since the seeds obtained from the harvest can be used as planting materials for subsequent cropping season. Worku and Zelleke (2007) reported that open-pollinated maize varieties yield higher than local varieties because they are more effective in transferring assimilates to their ear sink. Tolera et al. (1999) suggested that breeders should select maize varieties that combine high grain yield and desirable stover characteristics because of large differences that exist between cultivars. Odeleye and Odeleye (2001) reported that maize varieties differ in their growth characters, yield and its components, and therefore suggested that breeders must put these factors into consideration during their breeding programs. Iken and Anusa (2004) recommended an optimum plant population of 53,333 plants/ha for maximum yield of maize. Their report indicated that this is obtainable using a spacing of $75 \mathrm{~cm} \times 25 \mathrm{~cm}$ at 1 plant per stand or $75 \mathrm{~cm} \times 50 \mathrm{~cm}$ at 2 
plants per stand. Azam et al. (2007) reported that spacing of $75 \mathrm{~cm}$ x $35 \mathrm{~cm}$ resulted in increased grain yield of maize, while $75 \mathrm{~cm}$ x $15 \mathrm{~cm}$ gave maximum cob weight. Similar report by Allessi and Power (2004) revealed that maize cob weight decreased with increased plant population.

At present, some farmers in Asaba area sow any maize variety of their choice at $90 \mathrm{~cm} \times 30 \mathrm{~cm}, 90 \mathrm{~cm} \times 20 \mathrm{~cm}$, $90 \mathrm{~cm} \times 50 \mathrm{~cm}$ or $75 \mathrm{~cm}$ x $50 \mathrm{~cm}$ which do not translate into the expected high yield in the study area. The broad objective of this study, therefore, was to identify the best open-pollinated variety of maize for Asaba area and the most appropriate spacing for the variety.

The specific objectives were to:

(i). determine the effects of variety and spacing on yield indices of maize, and

(ii). identify the best open-pollinated variety and spacing for the crop.

\section{Materials and Methods}

\subsection{Site Description}

The study was carried out in the Teaching and Research Farm of Delta State University, Asaba Campus from March to December in 2008, and replicated between March and December, 2009. Asaba is located at latitude $06^{\circ}$ $14^{\prime} \mathrm{N}$ and longitude $06^{\circ} 49^{\prime} \mathrm{N}$ of the equator. It lies in the tropical rainforest zone dominated by mangrove, fresh water, swamps, humid forests and secondary vegetation (NEST, 1991). Its climate is influenced by the movement of the Inter-Tropical Discontinuity (ITD). The ITD is made up of two wind systems, namely the moisture-laden South-West monsoon from the Atlantic Ocean and the dry cold North-East trade wind from the Sahara desert. The South-West Trade wind most significantly determine the climatic condition of Asaba area of Delta State. Asaba is characterized by rainy season between April and October, with annual mean-rainfall of $1500 \mathrm{~mm}$ and $2000 \mathrm{~mm}$ maximum. The distribution is bimodal with peak in July and September, coupled with a period of low precipitation in August. Mean temperature is $23.8^{\circ} \mathrm{C}$, with $37.3^{\circ} \mathrm{C}$ as maximum. Relative humidity is $77.2 \%$, the mean monthly soil temperature at $100 \mathrm{~m}$ depth is $20.3{ }^{\circ} \mathrm{C}$, while sunshine is at 4.8 bars (Meteorological Office, Asaba, 2003).

\subsection{Pre-Planting Soil Analysis}

Representative surface soils $(0-20 \mathrm{~cm})$ were sampled with a tubular sampling auger. These soil samples were air-dried at room temperature for 5 days and crushed to pass through a $2 \mathrm{~mm}$ mesh sieve. Sub-samples from the bulked soil sample were further grounded to pieces to pass through $100 \mathrm{~mm}$-mesh sieve for the determination of organic matter. The rest of the samples were then analyzed to determine the physical and chemical properties of the soil. The analysis was done at Delta State University, Asaba campus.

\subsection{Analytical Procedure}

\subsubsection{Physical Properties}

Particle size distribution: Particle size distribution was analyzed using the Bouyoucos hydrometer method in which 0.5 N Sodium hexameta-phosphate was used as dispersant (Landon, 1991).

Bulk density: The bulk density (Bd) was determined by Core-method.

Particle density: This was determined by pycometer or specific gravity bottle method as described by Bowles (1992).

\subsubsection{Chemical Properties}

Soil $\mathrm{pH}$ : This was determined in soil: water suspension (1:1) using glass electrode $\mathrm{pH}$-meter as described by Mclean (1982).

Organic carbon: This was determined using the wet oxidation method of Walkley and Black (Walkley \& Black, 1945).

Total nitrogen: This was determined using the modified K. Jeldah distillation method as described by Landon (1991).

Exchangeable cations (EC) and Effective cation exchange capacity (ECEC): Exchangeable cations were determined by extracting the cations with IN ammonium acetate (IN, NHOAC) as displacing solution, buffered at $\mathrm{pH}_{7}$ as described by Brady and Weils (1999). The extract was then determined electrochemically using atomic absorption spectrophometry. The effective cation exchange capacity (ECEC) was calculated as the sum of exchangeable bases ( $\mathrm{Ca}, \mathrm{Mg}, \mathrm{K}$ and $\mathrm{Na}$ ) and exchangeable $\mathrm{A} 1$ and $\mathrm{H}$ expressed in $\mathrm{cmol} \mathrm{kg}^{-1}$ of soil.

Exchangeable acidity: This was determined by titration method as described by Juo (1981). The exchangeable 
$\mathrm{H}^{+}$and $\mathrm{Al}^{++}$were then expressed in cmolkg ${ }^{-1}$ of soil.

Available phosphorus: This was determined by Bray No.1 method as described by Landor (1991).

Cation exchangeable capacity: This was determined by neutral $\mathrm{NH}_{4}$ - Acetate placement method using the procedure of Anderson and Ingram (1996).

\subsection{Experimental Design}

It was a factorial experiment carried out in a Randomized Complete Block Design (RCBD) with three replicates.

\subsection{Agronomic Practices}

The agronomic practices carried out were land preparation and plot layout, planting and weeding.

\subsection{Land Preparation and Plots Layout}

The land was ploughed and harrowed using a tractor. Four blocks (or replicates) consisting of 12 plots each were laid out, each plot measured $2.6 \mathrm{~m} \times 2.25 \mathrm{~m}$ and was separated from one another with a space of $0.5 \mathrm{~m}$. Alley pathways of $1 \mathrm{~m}$ separated one block from the other, and the total number of plots laid out in the entire experiment were 48 .

\subsection{Planting}

Maize seeds were sown in the plots at the rate of 1 seed per hole at a depth of 2-3 cm under three different plant spacings ( $75 \mathrm{~cm}$ x $35 \mathrm{~cm}, 75 \mathrm{~cm}$ x $25 \mathrm{~cm}, 75 \mathrm{~cm} \times 15 \mathrm{~cm}$ ).

Fertilizer Application: During the third week after sowing, NPK 20:10:10 fertilizer was applied to the topsoil of maize plant at the rate of $450 \mathrm{~kg}^{-1}$ as recommended by Enujeke (2013).

Weeding: Weeding was done three times using a hoe.

Data Collection: Data collected at the end of the $16^{\text {th }}$ week after sowing were number of cobs/plant, cob length $(\mathrm{cm})$, number of grains/cob and grain weight $(\mathrm{t} / \mathrm{ha})$. Number of cobs/plant and number of grains/cob were determined by direct counting, Cob length was measured using tape rule, and grain weight was measured using a weighing scale.

Statistical analysis: Data collected was subjected to analysis of variance (ANOVA) and means were separated with Duncan Multiple Range Test (DMRT) using SAS (2010).

\section{Results}

\subsection{Soil Physico-Chemical Properties of the Experimental Site}

The pre-physico-chemical properties of the experimental site are shown in Table 1. The result showed that sand was predominant in the study area, and that it gradually decreased down the soil profile. Texturally, the soil of the experimental site is classified as sandy loam. The soil is acidic with $\mathrm{pH}$ of 6.2 in $\mathrm{H}_{2} \mathrm{O}$ and 5.6 in $\mathrm{CaCl}_{2}$. The organic matter content and total nitrogen were low with values of $1.22 \mathrm{~g} \mathrm{~kg}^{-1}$ and $0.113 \mathrm{~g} \mathrm{~kg}^{-1}$. The available $\mathrm{P}$ was high with value of $26.5 \mathrm{mg} \mathrm{kg}^{-1}$. The exchangeable cations ( $\mathrm{Ca}, \mathrm{Mg}, \mathrm{Na}$ and $\mathrm{K}$ ) were equally low in status with values of $2.6 \mathrm{cmol} \mathrm{kg}^{-1}$ for $\mathrm{Ca}^{2+}$ and $0.9 \mathrm{cmol} \mathrm{kg}^{-1}$ for $\mathrm{Mg}^{2+}$. The value obtained for $\mathrm{Na}^{+}$was $0.57 \mathrm{cmol} \mathrm{kg}^{-1}$, which was moderate while that for $\mathrm{K}^{+}$was $0.08 \mathrm{cmol} \mathrm{kg}^{-1}$, which was low. The CEC was 4.15 , while ECEC was $5.6 \mathrm{cmol} \mathrm{kg}^{-1}$, which were generally low. The exchangeable acidity was only trace for $\mathrm{Al}^{3+}$ and characteristically low for $\mathrm{H}^{+}$with a value of $1.4 \mathrm{cmol} \mathrm{kg}^{-1}$

Table 1. Physico-chemical properties of experimental site

\begin{tabular}{llll}
\hline Soil Property & Value & Interpretation \\
\hline Particle Size Distribution (\%) & & \\
& Coarse sand & 38 & \\
Fine sand & 41 & \\
Silt & 9 & \\
Clay & 12 & \\
Texture & & Sandy loam \\
& & \\
\hline
\end{tabular}




\begin{tabular}{llll}
\hline $\mathrm{pH}$ & $\mathrm{H}_{2} \mathrm{O}$ & 6.2 & Acidic \\
& $\mathrm{CaCl}$ & 5.6 & Acidic \\
Organic & Carbon $\mathrm{gkg}^{-1}$ & 0.71 & \\
Organic & Matter $\mathrm{gkg}^{-1}$ & 1.22 & Very low \\
Total & Nitrogen $\mathrm{gkg}^{-1}$ & 0.113 & Low \\
Available & $\mathrm{P}(\mathrm{ppm})$ & 26.5 & \\
Exchangeable bases $\left(\mathrm{cmol}^{-1} \mathrm{~kg}^{-1}\right)$ & & \\
& $\mathrm{Na}^{+}$ & 0.57 & Moderate \\
& $\mathrm{K}^{+}$ & 0.08 & Very low \\
& $\mathrm{Ca}^{2+}$ & 2.60 & Low \\
& $\mathrm{Mg}^{2+}$ & 0.90 & Low \\
Cation Exchange Capacity & 4.15 & \\
Exchangeable acidity $\left(\mathrm{cmol}^{2+} \mathrm{kg}^{-1}\right)$ & & \\
& $\mathrm{Al}^{3+}$ & & \\
& $\mathrm{H}^{+}$ & Trace & \\
Effective cation Exchangeable capacity $\left(\mathrm{Cmol} / \mathrm{kg}^{-1}\right)$ & 5.6 & \\
\hline
\end{tabular}

\subsection{Effects of Variety and Spacing on Number of Cobs/Plant of Open-Pollinated Maize}

The responses of number of cobs/plant of open-pollinated maize are shown in Tables 2, 4 and 5. There were significant differences in number of cobs/plants of some of the varieties sown. Table 4 (2008 analysis) indicated that open-pollinated varieties BR9922-DMRSF 2 and AMATZBRC $\mathrm{D}_{2} \mathrm{WB}$ had higher mean number of cobs/plant of 1.7 than other varieties, and they were statistically similar. Suwan $-1-\mathrm{R}$ variety had the lowest mean number of cobs/plant. Table 5 (2009 analysis), however, clearly showed that variety BR9922-DMRSF 2 with mean number of cobs/plant of 1.7 was superior to other varieties investigated. Similar trend was observed in Table 2 (2008 analysis) where both open-pollinated varieties BR9922-DMRSF 2 and $\mathrm{AMATZBRC}_{2} \mathrm{WB}$, had the highest number of cobs/plant of 1.7 and were statistically similar. These were followed by ACR 97 (1.6). In contrast, Suwan 1-SR had the lowest number of cobs/plant (1.4). Based on spacing, the plants sown at $75 \mathrm{~cm} \mathrm{x} 15 \mathrm{~cm}$ had the highest number of cobs/plant (1.9), while the lowest number of cobs/plant was observed with planting conditions of $75 \mathrm{~cm} \times 35 \mathrm{~cm}$ (1.2). The order of performance with respect to highest number of cobs/plant based on spacing was $75 \mathrm{~cm} \times 15 \mathrm{~cm}>75 \mathrm{~cm} \times 25 \mathrm{~cm}>75 \mathrm{~cm} \times 35 \mathrm{~cm}$. Except AMATZBRC $\mathrm{C}_{2} \mathrm{WB}$ variety for which we noted a reduction in the number of cobs/plant, all other varieties have developed the same trend during 2009.The results obtained from the interaction of variety and spacing (Tables 4 and 5) indicated that except variety $\mathrm{x}$ space interaction, all other parameters investigated were significantly $(\mathrm{P}<0.05)$ different and affected number of cobs/plant of maize in 2008 and 2009.

\subsection{Effects of Variety and Spacing on Cob Length of Open-Pollinated Maize}

The responses of cob length of open-pollinated maize to variety and spacing are shown in Tables 2, 4 and 5 . There were significant differences in cob length of maize. In 2008, variety BR9922-DMRSF 2 had the highest cob length, $(25.7 \mathrm{~cm})$, followed by variety Suwan-1-SR $(21.7 \mathrm{~cm})$. AMATZBRC 2 WB variety had the lowest cob length $(18.7 \mathrm{~cm})$. With respect to spacing, wider-spaced plants had higher cob length. Plants sown on $75 \mathrm{~cm} \times 35$ $\mathrm{cm}$ had the highest cob length $(26.0 \mathrm{~cm})$, while plants sown at $75 \mathrm{~cm} \mathrm{x} 15 \mathrm{~cm}$ had the lowest cob length $(18.6$ $\mathrm{cm})$. The superiority in cob length of maize based on spacing was $75 \mathrm{~cm} \times 35 \mathrm{~cm}>75 \mathrm{~cm} \times 25 \mathrm{~cm}>75 \mathrm{~cm} \times 15$ $\mathrm{cm}$. Table 4 (2008 analysis) showed that variety BR9922-DMRSF ${ }_{2}$ had the highest value with respect to mean cob length of maize $\left(25.7 \mathrm{~cm}\right.$ ), while $\mathrm{AMATZBRC}_{2} \mathrm{WB}$ had the lowest value of $18.7 \mathrm{~cm}$. Table 5 (2009 analysis) also showed similar trend. The results of interaction showed that variety and space were significantly $(\mathrm{P}<0.05)$ different and affected cob length of maize (Tables 4 and 5). 
Table 2. Effects of variety and spacing on number of cobs per plant and cob length of maize in 2008 and 2009

\begin{tabular}{lcccccc}
\hline & \multicolumn{3}{c}{ No of cobs per plant } & \multicolumn{3}{l}{ Cob length $(\mathrm{cm})$} \\
\hline & 2008 & 2009 & Mean & 2008 & 2009 & Mean \\
\cline { 2 - 7 } Variety & & & & & & \\
Suwan-1-SR & $1.4_{\mathrm{b}}$ & $1.4_{\mathrm{b}}$ & $1.4_{\mathrm{c}}$ & $21.7_{\mathrm{bc}}$ & $22.9_{\mathrm{bc}}$ & $22.3_{\mathrm{b}}$ \\
ACR 97 & $1.6_{\mathrm{ab}}$ & $1.6_{\mathrm{ab}}$ & $1.6_{\mathrm{ab}}$ & $21.0_{\mathrm{b}}$ & $22.2_{\mathrm{b}}$ & $21.6_{\mathrm{c}}$ \\
BR9922-DMRSF $_{2}$ & $1.7_{\mathrm{a}}$ & $1.7_{\mathrm{a}}$ & $1.7_{\mathrm{a}}$ & $25.7_{\mathrm{a}}$ & $27.7_{\mathrm{a}}$ & $26.7_{\mathrm{a}}$ \\
AMATZBRC $_{2} \mathrm{WB}$ & $1.7_{\mathrm{a}}$ & $1.4_{\mathrm{b}}$ & $1.5_{\mathrm{b}}$ & $18.7_{\mathrm{c}}$ & $19.5_{\mathrm{c}}$ & $19.1_{\mathrm{d}}$ \\
Spacing $(\mathrm{cm})$ & & & & & & \\
$75 \times 15$ & $1.9_{\mathrm{a}}$ & $1.9_{\mathrm{a}}$ & $1.9_{\mathrm{a}}$ & $18.6_{\mathrm{c}}$ & $20.1_{\mathrm{c}}$ & $19.4_{\mathrm{c}}$ \\
$75 \times 25$ & $1.7_{\mathrm{b}}$ & $1.6_{\mathrm{b}}$ & $1.7_{\mathrm{b}}$ & $21.0_{\mathrm{b}}$ & $21.8_{\mathrm{b}}$ & $21.4_{\mathrm{b}}$ \\
$75 \times 35$ & $1.2_{\mathrm{c}}$ & $1.0_{\mathrm{c}}$ & $1.1_{\mathrm{c}}$ & $26.0_{\mathrm{a}}$ & $27.3_{\mathrm{a}}$ & $26.7_{\mathrm{a}}$
\end{tabular}

Means with the same letters under the same column are not significant $(\mathrm{P}>0.05)$ different using Duncan Multiple Range Test (DMRT).

\subsection{Effects of Variety and Spacing on Grain Weight (t/ha) of Open-Pollinated Maize}

The responses of grain weight of open-pollinated maize to variety and spacing are shown in Tables 3, 4 and 5 . There were significant differences in grain weight of the varieties tested. Table 4 (2008 analysis) showed that the mean grain weight of variety BR9922-DMRSF 2 was highest $(4.7 \mathrm{t} / \mathrm{ha})$. It was also highest in 2009 (5.7 t/ha Table 5). Based on spacing, plants sown at $75 \mathrm{~cm} \times 15 \mathrm{~cm}$ had the highest grain weight while plants sown at spacing of $75 \mathrm{~cm} \times 35 \mathrm{~cm}$ had the lowest grain weight. Table 3 (2008 analysis) also showed that variety BR9922-DMRSF 2 had the highest grain weight $(4.7 \mathrm{t} / \mathrm{ha})$, followed by Suwan-1-SR which had grain weight of $(4.2 \mathrm{t} / \mathrm{ha})$. AMATZBRC $\mathrm{ABB}_{2} \mathrm{Wad}$ the lowest grain weight $(3.5 \mathrm{t} / \mathrm{ha})$. The superiority in grain weight based on variety was BR9922-DMRSF $2>$ Suwan -1-SR $>$ ACR97 $>$ AMATZBRC $_{2}$ WB. With respect to spacing, plants sown on $75 \mathrm{~cm} \times 15 \mathrm{~cm}$ had the highest grain weight $(5.0 \mathrm{t} / \mathrm{ha})$, while plants sown at $75 \mathrm{~cm} \times 35 \mathrm{~cm}$ had the lowest grain weight (3.0t/ha). The superiority in grain weight based on spacing was $75 \mathrm{~cm} \mathrm{x} 15 \mathrm{~cm}>75 \mathrm{~cm} \times 25$ $\mathrm{cm}>75 \mathrm{~cm}$ x $35 \mathrm{~cm}$. Grain weight followed the same trend in 2009. The result of interaction (Tables 4 and 5) showed that except variety $\mathrm{x}$ space interaction, other parameters such as variety, space were significantly $(\mathrm{P}<$ 0.05) different and affected changes in grain weight of maize in 2008 and 2009.

\subsection{Effects of Variety and Spacing on Number of Grains/Cob of Open-Pollinated Maize}

The effects of variety and spacing on number of grains/cob of open-pollinated maize are shown in Table 3, 4 and 5. There were significant differences in number of grains/cob of varieties investigated. Table 4 (2008 analysis) indicated that mean number of grains/cob was highest with variety BR9922-DMRSF 2 (460.0). It was also highest with the same variety in 2009 (467.7 -Table 5). Wider-spaced crops had higher number of grains/cob than narrower-spaced plants. Similar trend was observed in Table 3 (2008 analysis) where variety BR9922-DMRSF 2

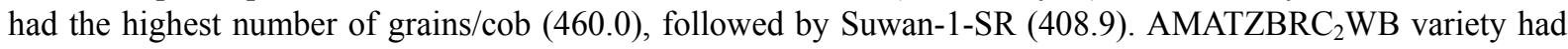
the lowest number of grains/cob (329.3). The order of superiority in number of grains/cob based on variety was BR9922-DMRSF ${ }_{2}>$ Suwan-1-SR $>$ ACR97 $>$ AMATZBRC $_{2}$ WB. Based on spacing, plants sown at $75 \mathrm{~cm} \times 35$ $\mathrm{cm}$ had the highest number of grains/cob (432.0), while plants sown at $75 \mathrm{~cm} \times 15 \mathrm{~cm}$ had the lowest number of grains/cob (363.0). The superiority in number of grains/cob of maize based on spacing was $75 \mathrm{~cm} \times 35 \mathrm{~cm}>75$ $\mathrm{cm} \times 25 \mathrm{~cm}>75 \mathrm{~cm} \times 15 \mathrm{~cm}$. The results of interaction (Tables 4 and 5) indicated that variety and space were significantly $(\mathrm{P}<0.05)$ different and affected number of grains/cob of maize in 2008 and 2009. Variety x space interaction was not significantly $(\mathrm{P}>0.05)$ different and did not affect changes in number of grains/cob of maize. 
Table 3. Effects of variety and spacing on grain weight of maize and number of grains per cob of maize in 2008 and 2009

\begin{tabular}{lcccccc}
\hline & \multicolumn{3}{c}{ Grain weight of maize (t/ha) } & \multicolumn{3}{c}{ Number of grains per cob } \\
\hline & 2008 & 2009 & Mean & 2008 & 2009 & Mean \\
\hline Variety & & & & & & \\
Suwan-1-SR & $4.2_{\mathrm{b}}$ & $4.3_{\mathrm{b}}$ & $4.2_{\mathrm{b}}$ & $408.9_{\mathrm{b}}$ & $412.0_{\mathrm{b}}$ & $410.5_{\mathrm{b}}$ \\
ACR 97 & $3.7_{\mathrm{c}}$ & $4.1_{\mathrm{c}}$ & $3.9_{\mathrm{c}}$ & $396.2_{\mathrm{c}}$ & $402.6_{\mathrm{c}}$ & $399.5_{\mathrm{c}}$ \\
BR9922-DMRSF 2 & $4.7_{\mathrm{a}}$ & $4.9_{\mathrm{a}}$ & $4.8_{\mathrm{a}}$ & $460.0_{\mathrm{a}}$ & $467.7_{\mathrm{a}}$ & $463.9_{\mathrm{a}}$ \\
AMATZBRC $_{2} \mathrm{WB}$ & $3.5_{\mathrm{d}}$ & $3.7_{\mathrm{d}}$ & $3.6_{\mathrm{d}}$ & $329.3_{\mathrm{d}}$ & $341.3_{\mathrm{d}}$ & $335.3_{\mathrm{d}}$ \\
Spacing $(\mathrm{cm})$ & & & & & & \\
$75 \times 15$ & $5.0_{\mathrm{a}}$ & $5.2_{\mathrm{a}}$ & $5.1_{\mathrm{a}}$ & $363.0_{\mathrm{c}}$ & $369.0_{\mathrm{c}}$ & $366.0 \mathrm{~s}_{\mathrm{c}}$ \\
$75 \times 25$ & $4.2_{\mathrm{b}}$ & $4.3_{\mathrm{b}}$ & $4.3_{\mathrm{b}}$ & $401.3_{\mathrm{b}}$ & $408.4_{\mathrm{b}}$ & $404.9_{\mathrm{b}}$ \\
$75 \times 35$ & $3.0_{\mathrm{c}}$ & $3.2_{\mathrm{c}}$ & $3.1_{\mathrm{c}}$ & $432.0_{\mathrm{a}}$ & $440.5_{\mathrm{a}}$ & $436.3_{\mathrm{a}}$ \\
\hline
\end{tabular}

Means with the same letters under the same column are no significant $(\mathrm{P}>0.05)$ using Duncan Multiple Range Test (DMRT).

Table 4. Effects of interaction of variety and spacing on grain yield indices of maize in 2008

\begin{tabular}{|c|c|c|c|c|c|}
\hline & & No. of Cob/plant & Cob length $(\mathrm{cm})$ & Grain Weight $\left(\right.$ tha $\left.^{1}\right)$ & No. of Grain/cob \\
\hline Variety & Spacing $(\mathrm{cm})$ & & & & \\
\hline \multirow{3}{*}{ Suwan-1-SR } & $75 \times 15$ & 1.7 & 18.7 & 5.1 & 386.7 \\
\hline & $75 \times 25$ & 1.7 & 20.6 & 4.6 & 407.3 \\
\hline & $75 \times 35$ & 1.0 & 26.0 & 2.9 & 432.7 \\
\hline \multirow{5}{*}{ ACR 97} & Mean & 1.4 & 21.8 & 4.2 & 408.9 \\
\hline & $75 \times 15$ & 2.0 & 18.0 & 4.7 & 349.3 \\
\hline & $75 \times 25$ & 1.7 & 20.3 & 3.6 & 406.7 \\
\hline & $75 \times 35$ & 1.0 & 24.7 & 2.8 & 432.7 \\
\hline & Mean & 1.6 & 21.0 & 3.7 & 396.2 \\
\hline \multirow{4}{*}{ BR992-DMRSRF $_{2}$} & $75 \times 15$ & 2.0 & 22.3 & 5.7 & 412.0 \\
\hline & $75 \times 25$ & 2.0 & 25.3 & 4.8 & 461.3 \\
\hline & $75 \times 35$ & 1.0 & 29.3 & 3.7 & 506.7 \\
\hline & Mean & 1.7 & 25.7 & 4.7 & 460.0 \\
\hline \multirow{4}{*}{ AMATZBE $\mathrm{C}_{2}$ WB } & $75 \times 15$ & 2.0 & 15.3 & 4.6 & 304.0 \\
\hline & $75 \times 25$ & 1.3 & 17.7 & 3.6 & 330.0 \\
\hline & $75 \times 35$ & 1.7 & 23.0 & 2.4 & 354.0 \\
\hline & Mean & 1.7 & 18.7 & 3.5 & 329.3 \\
\hline Variety & & $*$ & $*$ & $*$ & $*$ \\
\hline Space & & $*$ & $*$ & $*$ & $*$ \\
\hline Variety x space & & $*$ & $*$ & ns & Ns \\
\hline
\end{tabular}

Legend: * = significant at 0.05 level of probability, ns = not significant. 
Table 5. Effects of Interaction of variety and spacing on grain yield indices of maize 2009

\begin{tabular}{cccccc}
\hline & & No. of cobs/plant & Cob length $(\mathrm{cm})$ & Grain weight $\left(\right.$ tha $\left.{ }^{-1}\right)$ & No. of grain/cob \\
\hline Variety & Spacing $(\mathrm{cm})$ & & & & \\
Suwan-1-SR & $75 \times 15$ & 1.6 & 20.0 & 5.1 & 384.6 \\
& $75 \times 25$ & 1.6 & 21.3 & 4.7 & 412.6 \\
& $75 \times 35$ & 1.0 & 27.3 & 3.0 & 438.6 \\
& Mean & 1.4 & 22.9 & 4.3 & 412.0 \\
& $75 \times 15$ & 2.0 & 16.6 & 4.8 & 312.0 \\
AMATZBRC 2 WB & $75 \times 25$ & 1.3 & 17.3 & 3.7 & 342.0 \\
& $75 \times 35$ & 1.0 & 24.6 & 2.6 & 370.0 \\
& Mean & 1.4 & 19.5 & 3.7 & 341.3 \\
BR9922-DMRSF 2 & $75 \times 25$ & 2.0 & 24.6 & 5.9 & 422.0 \\
& $75 \times 35$ & 1.0 & 26.6 & 4.9 & 467.0 \\
& Mean & 1.7 & 32.0 & 3.8 & 514.0 \\
ACR 97 & $75 \times 15$ & 2.0 & 27.7 & 4.9 & 467.7 \\
& $75 \times 25$ & 1.6 & 19.3 & 5.1 & 356.6 \\
Variety x space & $75 \times 35$ & 1.0 & 22.0 & 3.8 & 412.0 \\
Variety & Mean & 1.6 & 25.3 & 3.4 & 439.3 \\
\hline & & $*$ & 22.2 & 4.1 & 402.6 \\
\hline
\end{tabular}

Legend: * = significant at 0.05 level of probability, ns = not significant.

\section{Discussion}

\subsection{Physico-Chemical Properties of Experimental Site}

The sandy loam texture of the experimental site may be attributed to the parent material (PM) from which the soil was formed and the climate of the area. The soil might be formed from sandstone and quartz parent materials (Brady \& Weils, 1999).

The weakly acid nature of the soil of the area may be traced to the marked leaching of exchangeable bases by the high rainfall in the environment (Esu, 2001). The low organic matter status of the experimental site could be attributed to the rapid decomposition of organic matter due to high solar radiation and the annual seasonal bush burning which tend to deplete organic matter accumulation in the soil (Landon, 1991). The low level of total nitrogen could possibly be due to low organic matter content of the soil and the leaching of nitrate by torrential rainfall prevalent in the environment (Amalu, 2001; Olatunji, 2007). The high level of Phosphorus may be attributed to: (i) History of land use and cultural practices associated with the land (Nnaji et al., 2002). (ii) The parent material from which the soil was formed (Nnaji et al., 2002). (iii) The soil may not be highly acidic as to cause high level of P fixation (Isirimah et al., 2003; Omokri et al., 2007). The low values of exchangeable cation may be attributed to the leaching of bases from the soil by high rainfall in the area. The low cation exchange capacity could be attributed to the low organic matter (OM) content of the soil. (FMANR, 1990) noted that soils of the study area was dominated by Fe oxide and kaolinites which are low in basic cations. The exchangeable acidity was low possibly because of leaching of basic cations by torrential rainfall. The results generally are in harmony with the findings of Osaretin et al. (2006), Olatunji et al. (2007) and the results of soil fertility evaluation in the region.

\subsection{Effects of Variety and Spacing on Number of Cobs/Plant Open-Pollination Maize}

Open-pollinated variety BR9922-DMRSF 2 had the highest number of cobs/plant of maize compared with other 
variety evaluated in the study. This could be attributed to genetic differences that exist between maize cultivars with respect to yield and its components, and ability to combine desirable traits for increased productivity. This is similar to the findings of Odeleye and Odeleye (2001) who reported that maize varieties differ in their growth characters, yield and its components, and therefore suggested that breeders must select most promising varieties which have the ability to combine good traits in their breeding programs. It is also similar to the finding of Tolera et al. (1999) who suggested that breeders should select maize varieties that combine high yield with desirable stover characteristics because of the large differences that exist between cultivars.

Plant sown on spacing of $75 \mathrm{~cm} \times 15 \mathrm{~cm}$ had higher number of cobs/plant than plants sown on wider spacing possibly because narrow - spaced crops resulted in higher plant density and more number of cobs. This is similar to the findings of Kim (1997) and Olakojo et al. (1993) who reported that highest number of cobs and higher grain yield were obtained from higher plant density due to narrow spacing. It is also consistent with the findings of Widdicombe and Thelen (2000) who reported yield increase of $10 \%$ with narrow spacing.

\subsection{Effects of Variety and Spacing on Cob Length of Open-Pollinated Maize}

Open-pollinated variety BR9922-DMRSF ${ }^{2}$ had highest cob length than other varieties investigated. This could be attributed to genetic attributes or traits associated with the variety with respect to high yield, adaptation to environmental stresses and disease resistance. This is similar to the findings of Udoh (2005) who attributed the high yield of some improved or open-pollinated maize varieties to differences in genetic make - up disease resistance, and adaptation to environmental condition. Increased intra-row spacing of $35 \mathrm{~cm}$ resulted in higher cob length of maize possibly because of decrease in competition for natural resources needed by plants for enhanced growth and yield. This is similar to the findings of Hussein et al. (2008) who reported that wider-spaced crops suffered less competition for such resources as sunlight and plant nutrients hence they obtained highest values of ear length, ear weight and other grain yield indices.

\subsection{Effects of Variety and Spacing on Grain Weight of Open-Pollinated Maize}

With respect to grain weight, variety BR9922-DMRSF ${ }^{2}$ out-yielded other varieties tested possibly because it has higher ability to conduct and partition photosynthetic materials through its stomata towards economic yield. This is similar to the findings of Costa and Campos (1990); Gardner et al. (1990) and Zaki et al. (1999) which attributed yield differences in maize cultivars to stomata conductance value and to differences between genotypes in partitioning of photosynthetic materials towards economic yield. The higher grain weight of BR9922-DMRSF ${ }^{2}$ over other varieties may also be due to variations in genetic structure, mineral concentration and potentials to transport photosynthetic materials within plants as reported by Clark et al. (1997).

Grain weight of maize obtained from plants sown at $75 \mathrm{~cm} \times 15 \mathrm{~cm}$ was higher than those sown at wider spacing possibly because more number of cobs was obtained from the increased plant population. This is similar to the findings of Olufajo (1992) and Muoneke et al. (2007) who reported increased number of cobs and higher grain yield obtained from higher plant density due to narrow spacing. It is also consistent with the findings of Azam et al. (2007) and Alford et al. (2008) who reported that growing crops in narrow rows reduces weed biomass and increases the interception of light which could lead to increase in yield.

\subsection{Effects of Variety and Spacing on Number of Grains/Cob of Open-Pollinated Maize}

Among the open-pollinated maize varieties investigated, variety BR9922-DMRSF ${ }^{2}$ had higher number of grains/cob possibly because it had more number of kernels that were formed in the ears which are more effective sink for carbohydrate synthesized in the leaves. This is consistent with the findings of Begna et al, (1997) who reported that higher grain yield among maize cultivar was due to the greater number of kernels that are formed in the ears which are more effective sink for carbohydrate synthesized in the leaves. It is also consistent with the findings of Ahmed and Sadek (1992) who reported that maize cultivars differ in their growth characters, yield and its components. Increased intra-row spacing of $35 \mathrm{~cm}$ resulted in higher number of grains $/ \mathrm{cob}$ possibly because wider-spaced plants experienced a decrease in competition for natural resources such as sunlight and soil nutrients. This is consistent with the findings of Roy and Biswas (1992) who reported that increased spacing of $25 \mathrm{~cm}$ resulted in maximum number of grains $/ \mathrm{cob}$ while spacing of $15 \mathrm{~cm}$ resulted in minimum number of grains/cob. It is also similar to the findings of Hussein et al. (2008) who reported that the higher values of number of grains per cob, ear length, ear weight, grain weight/cob and grain index were recorded when maize plants were sown at wider spacing (lower plant population of 2000 plants $/ \mathrm{ha}$ ), and attributed the results obtained to possible decrease in intra-specific competition for sunlight and soil nutrients. 
The present study provides unique information on the following:

(i) Open-pollinated maize variety BR9922-DMRSF 2 which had the highest number of cobs/plant and highest grain weight is superior to other varieties tested, and should be grown in the study area.

(ii) Spacing of $75 \mathrm{~cm} \times 15 \mathrm{~cm}$ which resulted in higher grain yield indices of maize should be adopted in maize production.

\section{References}

Agbato, S. O. (2003). Principles and Practices of crop production (pp. 57-62). Oyo: Odumatt press publisher.

Ahmed, A. M., \& Sadak, S. E. (1992). Growth and yield in some maize cultivars (Zea mays L.) grown in Egypt. Egypt Journal of Applied Sciences, 7(10), 328-343.

Alford, C. M., Miller, S. D., \& Cecil, J. T. (2008). Using row spacing to increase crop competition with weeds. $A$ paper presented at $5^{\text {th }}$ International Crop Science Congress 10-15 (pp. 10-15). U.S.A: Home Regional Institute Limited.

Allessi, J., \& Power, J. F. (2004). Effect of plant population, row spacing and relative maturity on dry land corn in the Northern plans. Agronomy Journal, 66(2), 316-319. http://dx.doi.org/10.2134/agronj1974.00021962006600020037x

Amalu, U. C., Esu, I. E., \& Nwulu, M. N. (2001). Fertility management of luvisols and Alfisols of South-East Nigeria. In proceedings of the $27^{\text {th }}$ Annual Conference of the soil Service Society of Nigeria, $5^{\text {th }}-9^{\text {th }}$ November, Calabar, Nigeria.

Anderson, J. M., \& Ingram, J. S. (1996). A hand book of Methods of Analysis CAB International, p. 38.

Azam, S., Ali, M., Amin, M., Bibi, S., \& Arif, M. (2007). Effect of plant population on maize hybrids. Journal of Agricultural and Biological Science, 2(1), 104-111.

Begna, S. H., Hamilton R. I., Dwyer, I. M., Slewart, D. W., \& Smith, D. L. (1997). Effect of population density and planting pattern on the yield and yield compaonents of leafy reduced stature maize in short season area science, Zeitschrift fur Acker and plan. Journal of Agronomy and crop Science, 179(1), 9-17. http://dx.doi.org/10.1111/j.1439-037X.1997.tb01142.x

Bowles, J. E. (1992). Engineering properties of soils and their management (4th ed., p. 241). Boston, U.S.A: McGrew Hill Publishers.

Brady, C., \& Weils, R. R. (1999). Nature and properties of Soil (12 ed., pp. 74 -114). New Delhi: Prentice Hall.

Clark, R. B., Zeto, S. K., Baligar, V. C., \& Ritchey, K. D. (1997). Growth traits and mineral concentrations of maize hybrids grown on unlimed and limed acid soil. Journal of Plant Nutrition, 20(12), 1773-1795. http://dx.doi.org/10.1080/01904169709365374

Costa, J. G., \& Campos, D. A. J. S. (1990). Maize cultivars recommended for the state of Acre. Counica de Tecnico unidade d'Exeecuo de Numbito Estand. No. 56, 4pp (c.f. Field Crop Abstracts 1991, volume 44, No.12).

DIPA. (2006). Handbook of Agriculture: facts and figures for farmers, students and all interested in farming. Directorate of Information and Publications of Agriculture (p. 435). Indian Council of Agricultural Research, New Delhi.

Dutt, S. (2005). A Handbook of Agriculture (pp. 116-118). India: ABD Publishers.

Enujeke, E. C. (2013). Nutrient content of Dry Matter of maize as affected by different levels of fertilizers in Asaba Area of Delta State. Sustainable Agriculture Research, 2(3), 76-85. http://dx.doi.org/10.5539/sar.v2n3p76

Esu, I. E. (2001). Pedological characterization of soils of Alluvial complex of Nigeria (pp. 171-190). Ibadan. Pedological handbook.

FAO. (2002). Fertilizer and the future. IFA/FAO Agriculture Conference on Global food security and the role of Sustainability Fertilization (pp. 1-2). Rome, Italy.

FMANR. (1990). Literature review of soil fertility. Investigation in Nigeria (in five volume), 3(2), 102-106.

Gardner, F. P., Alle, V., \& McCloud, D. E. (1990). Yield characteristics of ancient roses of maize compared to $\begin{array}{lllll}\text { modern } & \text { hybrid. } & \text { Agronomy } & \text { 80urnal, } & \text { 82(5), }\end{array}$ http://dx.doi.org/10.2134/agronj1990.00021962008200050003x 
Hussein, F., Abouziena, I. M., EL-Metwally, \& El-Dosoki, E. R. (2008). Effect of Plant Spacing and Weed Control Treatments on Maize Yield and Associated Weeds in Sandy Soils. Journal of Agriculture and Environmental Science, 4(1), 9-17.

IITA. (2001). Improved Maize Varieties for Sustainable Agriculture in Sub-Saharan Africa (pp. 1-16). International Institute of Tropical Agriculture, Ibadan, Nigeria.

Iken, J. E., \& Anusa, A. (2004). Maize Research and Production in Nigeria. African Journal of Biotechnology, 3(6), 302-307.

Iken, J. E., Anusa, A., \& Obaloju, V. O. (2001). Nutrient Composition and Weight Evaluation of some Newly Developed maize Varieties in Nigeria. Journal of Food Technology, 7, 25-28.

Isirimah, N. O., Dickson, A. A., \& Igwe C. (2003). Introductory soil Chemistry and Biology for Agriculture and Biotechnology (p. 103). Asia International Publishers Limited, Port-Harcourt, Nigeria.

Juo, A. S. R. (1981). Mineralogy of Acid Sands of Southern Nigeria. Soil Science Society of Nigeria, pp.19-26.

Kim, S. K. (1997). Achievement, challenges and future direction of hybrid maize research and product. In B. Badu-Apraku, M. O. Akoroda, M. Oedraw \& F. M. Quin (Eds.), Proceedings of Required Maize Workshop. IITA Cotonou, Benin Republic.

Landon, J. R. (1991). Brooker tropical soil manual. A handbook for soil survey in the tropics and subtropics (pp. 106-144). Longman Group. England.

McClean, E. O. (1982). Aluminum. In C. A. Black (Ed.), Methods of soil analysis part 2 (pp. 978-998). American Society of Agronomy.

Meteorological Office Asaba. (2003). Weather Characteristics of Delta State of Nigeria. Unpublished, 2, 2-21.

Muoneke, C. O., Ogwuche, M. A. O., \& Kalu, B. A. (2007). Effect of maize planting density on the performance of maize/soybean intercropping system in a guinea savannah agroecosystem. African Journal of Agricultural Research, 2(12), 667- 677.

Nest-Nigerian Environment Study Action Team. (1991). Nigerian threatened environment: A National Profile, p. 288.

Nnaji, G. U. (2008). Fertility status of some soils in Isoko South Local Government Area of Delta State (pp. 515-519). Proceedings of the Annual Conference of the Agricultural Society of Nigeria held n Ebonyi State University, Abakiliki.

Nnaji, G. U., Asadu, \& Mbagwu, J. S. C. (2002). Evaluation of the physico-Chemical properties of soils under selected agricultural land utilization types. Journal of Tropical Agriculture, Food, Environment and Extension, 3, 27-33.

Odeleye F. O., \& Odeleye, M. O. (2001). Evaluation of morphological and agronomic characteristics of two exolic and two adapted varieties of tomato (Lycopersicom esculentum) in South West Nigeria. Proceedings of the $19^{\text {th }}$ Annual Conference of HORTSON, (1), 140-145.

Olakojo, S. A., Ogundodede, B. A., \& Kogbe, J. O. S. (1993). Evaluation of Maize (Zea mays) Top crosses in a Rainforest Location. Biose Res. Comm, 11(2), 141-146.

Olatunji, C. A., Ighodo, \& Igiri, J. N. (2007). Soil survey report of the Niger Delta (p. 158). Federal Government Action of the Niger Delta.

Olufajo, O. O. (1992). Response of soybean to intercropping with maize in a sub-humid tropical environment. Tropical Oil seeds Journal, 1, 27-33.

Omokri, J. I., Nnaji, G. U., \& Uyovbisere, E. O. (2007). Assessment of the physical properties of Orogodo basin and the surrounding soils in Agbor, Delta State (pp. 358-362). Proceedings of the $31^{\text {st }}$ Conference of Soil Science Society of Nigeria held on the $13^{\text {th }}-17^{\text {th }}$ November, 2006 at Ahmadu Bello University, Zaria, Nigeria.

Osaretin, A. U., Jedeki, F. C., \& Odingo, F. M. (2006). Fertility status and classification of some tropical soil cateria. Tropical soils, 31(24), 38-52.

Roy, S. K., \& Biswas, P. K. (1992). Effect of plant density and detopping following silking on cob growth, fodder and grain yield of maize (Zea mays L.). Journal of Agricultural Science. Abstracted in Field Crop Abstract, 46, 1498, 1993. 
SAS Institute Inc. (2010). SAS User’s Guide. Statistics Version 5. SAS Institute, Inc., Raleigh, NC. p. 956.

Tolera, A., Berg, T., \& Sundstol, F. (1999). The effect of variety on maize grain and crop residue yield and nutritive value of the Stover. Journal of Animal feed Science and Technology, 79(3), 165-177. http://dx.doi.org/10.1016/S0377-8401(99)00025-5

Udoh, J. (2005). Crop Production Techniques for the Tropics Concept Publications Limited, Munshin, Lagos Nigeria. pp. 101-106.

Walkely, A., \& Black, I. A. (1945). An Examination of Detrigrareff methods for determining soil organic matter and proposed modification of the chronic and titration methods. Soil Science, 37, 29-38. http://dx.doi.org/10.1097/00010694-193401000-00003

Widdicombe, W. D., \& Thelen, K. D. (2000). Row width and plant density effects on corn grain production in the northern Corn Belt. Agronomy Journal, 94,102.0-1024.

Zaki, N. M., El-Gazar, M. M., El-Din, K. M. G., \& Ahmed, M. A. (1999). Partition and migration of photosynthates in some maize hybrids. Egypt Journal of Applied Sciences, 14(6), 117-139.

\section{Copyrights}

Copyright for this article is retained by the author(s), with first publication rights granted to the journal.

This is an open-access article distributed under the terms and conditions of the Creative Commons Attribution license (http://creativecommons.org/licenses/by/3.0/). 